\title{
Porticoccus litoralis gen. nov., sp. nov., a gammaproteobacterium isolated from the Yellow Sea
}

Correspondence

Jang-Cheon Cho

chojc@inha.ac.kr

\author{
Hyun-Myung Oh, Hana Kim, Kyung-Mi Kim, Gi-Sik Min \\ and Jang-Cheon Cho
}

Division of Biology and Ocean Sciences, Inha University, Incheon 402-751, Republic of Korea

\begin{abstract}
A marine bacterium, designated $\mathrm{IMCC} 2115^{\top}$, was isolated from coastal seawater (Yellow Sea, Korea) using a high throughput cultivation method based on dilution-to-extinction, and taxonomically investigated. Cells of the strain formed tiny, beige to off-white colonies and were Gram-stain-negative, obligately aerobic, chemoheterotrophic, non-motile cocci. Based on $16 \mathrm{~S}$ rRNA gene sequence comparisons, the strain was most closely related to the genera Marinimicrobium (92.0-92.4\%) and Microbulbifer (91.6-92.8\%), but phylogenetic trees showed that the strain formed a distinct phyletic line in the class Gammaproteobacteria adjacent to the OM60 and SAR92 clades. The DNA G+C content of the strain was $47.8 \mathrm{~mol} \%$ and the predominant cellular fatty acids were anteiso- $C_{15: 0}(67.6 \%)$, anteiso- $C_{17: 0}(14.4 \%)$ and $C_{16: 0}$ $(6.9 \%)$. The $16 \mathrm{~S}$ rRNA gene sequence analyses and phenotypic and chemotaxonomic tests allowed the differentiation of IMCC $2115^{\top}$ from other related genera in the class Gammaproteobacteria. Therefore, strain IMCC2115 ${ }^{\top}\left(=\mathrm{KCCM} 42369^{\top}=\mathrm{NBRC} 102686^{\top}\right)$ is proposed as the representative of a new genus and species, for which the name Porticoccus litoralis gen. nov., sp. nov. is proposed.
\end{abstract}

The oligotrophic marine gammaproteobacteria group was previously reported from a dilution-to-extinction study from the pelagic and coastal regions of the Pacific Ocean (Cho \& Giovannoni, 2004). Five distinct clades of oligotrophic marine gammaproteobacteria, including the OM60, BD1-7, KI89A, OM182 and SAR92 clades, and their designations were made only from 16S rRNA gene sequences of previously uncultured bacteria retrieved from various marine environments (Cho \& Giovannoni, 2004). The OM60 clade represented by strain HTCC2080 has been shown to contain aerobic, anoxygenic, phototrophic bacteria (Cho et al., 2007) and was most closely related to Haliea salexigens DSM $19537^{\mathrm{T}}$ (Urios et al., 2008) and Congregibacter litoralis KT71 (Eilers et al., 2001). The BD1-7 clade containing strain HTCC2143 was most closely related to Dasania marina KOPRI $20902^{\mathrm{T}}$ (Lee et al., 2007), forming a sister group to Spongiibacter marinus HAL40b ${ }^{\mathrm{T}}$ (Graeber et al., 2008). The SAR92 clade included the proteorhodopsin-containing gammaproteobacterium HTCC2207 (Stingl et al., 2007) and was most closely

The GenBank/EMBL/DDBJ accession number for the 16S rRNA gene sequence of strain IMCC2155' is EF468719.

A transmission electron micrograph of cells of strain IMCC2 $115^{\top}$ and a table detailing the cellular fatty acid profiles of strain IMCC $2115^{\top}$ and previously reported related taxa are available with the online version of this paper. related to the genus Microbulbifer (Gonzalez et al., 1997; Miyazaki et al., 2008; Tanaka et al., 2003; Yoon et al., 2003a, b, 2004, 2007), but is quite different ( $9 \%$ dissimilarity) in $16 \mathrm{~S}$ rRNA gene sequence comparisons (Stingl et al., 2007). This study was performed to describe a marine bacterium designated strain IMC $2115^{\mathrm{T}}$ that was phylogenetically closest to the genus Microbulbifer and the SAR92 clade on the basis of its $16 \mathrm{~S}$ rRNA gene sequence. On the basis of phylogenetic analysis and phenotypic characterization, a novel genus and species named Porticoccus litoralis gen. nov., sp. nov. is proposed for strain IMCC $2115^{\mathrm{T}}$ and is distinct from other members of the class Gammaproteobacteria.

A sample of coastal seawater was collected, at a depth of $1 \mathrm{~m}$, off the Port of Incheon $\left(37^{\circ} 19^{\prime} \mathrm{N} 126^{\circ} 33^{\prime} \mathrm{E}\right)$, Yellow Sea. Strain IMCC $2115^{\mathrm{T}}$ was isolated by using a dilution-toextinction culturing method in a low nutrient heterotrophic medium that was prepared with $0.2 \mu \mathrm{m}$-filtered and autoclaved seawater (Cho \& Giovannoni, 2004), and was successfully subcultured on marine agar 2216 (MA; Difco). After determination of the optimum growth temperature, cultures of IMCC $2115^{\mathrm{T}}$ were maintained routinely on $\mathrm{MA}$ at $20{ }^{\circ} \mathrm{C}$.

An almost complete sequence of the 16S rRNA gene (1497 bp) was obtained for strain IMCC $2115^{\mathrm{T}}$ as described previously (Cho \& Giovannoni, 2003). Phylogenetic ana- 
lyses, including multiple alignment of $16 \mathrm{~S}$ rRNA gene sequences, determination of sequence similarity and generation of phylogenetic trees, were performed in the ARB package (Ludwig et al., 2004) and PAUP (Swofford, 2002), as described previously (Cho \& Giovannoni, 2006). Sequence comparisons in the ARB database were also confirmed by using the EzTaxon server (Chun et al., 2007) and the results showed that strain IMCC $2115^{\mathrm{T}}$ was most closely related to Marinimicrobium koreense KCTC $12356^{\mathrm{T}}$ (92.4\%) (Lim et al., 2006) and marine gammaproteobacterium HTCC2207 (92.2\%, cultivated but without a validly published name), a member of the SAR92 clade (Stingl et al., 2007). Based on $16 \mathrm{~S}$ rRNA gene sequence similarities, other relatives of IMCC2 $115^{\mathrm{T}}$ included 'Candidatus Endobugula glebosa' (92.0\%) (Lim \& Haygood, 2004), Microbulbifer agarilyticus JAMB A3 ${ }^{\mathrm{T}}$ (91.9\%) (Miyazaki et al., 2008), Dasania marina KOPRI $20902^{\mathrm{T}}$ (91.7\%) (Lee et al., 2007), Cellvibrio japonicus NCIMB $10462^{\mathrm{T}}$ (91.7\%) (Humphry et al., 2003), Microbulbifer hydrolyticus IRE-31 ${ }^{\mathrm{T}}$ (91.6\%) (Gonzalez et al., 1997), Saccharophagus degradans $2-40^{\mathrm{T}}$ (91.5\%) (Gonzalez \& Weiner, 2000), Spongiibacter marinus HAL40b ${ }^{\mathrm{T}}$ (91.3\%) (Graeber et al., 2008), Teredinibacter turnerae $\mathrm{T} 7902^{\mathrm{T}}$ (91.1\%) (Distel et al., 2002), Congregibacter litoralis KT71
(90.1\%) (Eilers et al., 2001), Haliea salexigens 3X/A02/235 ${ }^{\mathrm{T}}$ $(90.1 \%)$ (Urios et al., 2008) and Simiduia agarivorans $\mathrm{SAl}^{\mathrm{T}}$ (Shieh et al., 2008) (90.0\%).

To clarify the phylogenetic position of strain IMCC $2115^{\mathrm{T}}$, 1125 unambiguously aligned nucleotide positions were used for phylogenetic analyses. Phylogenetic trees were inferred using the maximum-likelihood (Felsenstein, 1981), maximum-parsimony (Fitch, 1971) and neighbour-joining (Saitou \& Nei, 1987) algorithms. The robustness of tree topologies for the maximum-likelihood, maximum-parsimony and neighbour-joining trees were evaluated by using bootstrap analyses (Felsenstein, 1985) based on 100, 1000 and 1000 resamplings of the sequences, respectively. All of the phylogenetic trees generated in this study (Fig. 1) indicated that IMCC $2115^{\mathrm{T}}$ was distinctly grouped with uncultured bacterial clones D53 (Zeng et al., 2005) and ELB16-080 (Glatz et al., 2006). This phylogenetic inference together with the level of 16S rRNA gene sequence similarity between strain IMCC $2115^{\mathrm{T}}$ and other cultured representatives (16S rRNA similarities less than $92.4 \%$ ) suggested that the strain should be assigned to a novel genus within the class Gammaproteobacteria.

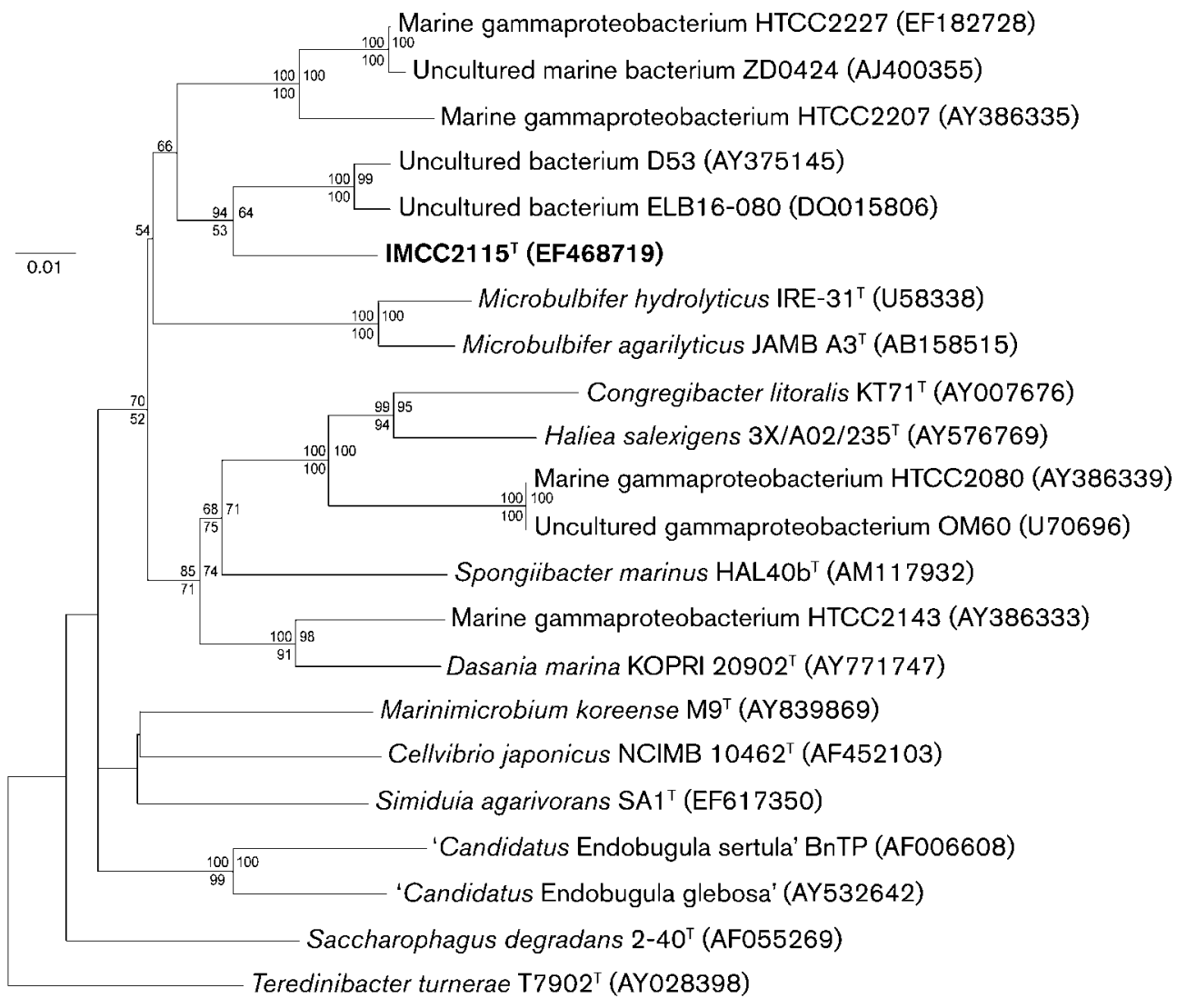

Fig. 1. Neighbour-joining phylogenetic tree based on 16S rRNA gene sequences, showing the relationships between strain IMCC $2115^{\top}$ and representatives of the related taxa. Bootstrap proportions (above 50\%) are shown from 1000,1000 and 100 resamplings for neighbour-joining, maximum-parsimony and maximum-likelihood analyses, respectively. Teredinibacter turnerae $\mathrm{T} 7902^{\top}$ (AY028398) was used as an outgroup. Bar, 1 substitution per 100 nucleotide positions. 
Cell morphology and size, colony morphology, size and colour, flagella and gliding motility, pigments, and ranges and optima of temperature, $\mathrm{pH}$ and salinity for growth were examined using cultures grown on/in MA or marine broth 2216 (MB; Difco) at $20{ }^{\circ} \mathrm{C}$, according to methods described in a previous study (Choi et al., 2007) as well as standard methods (Smibert \& Krieg, 1994). Basic biochemical tests and carbon source oxidation tests were performed in API 20NE and API ZYM strips (bioMérieux) and in Biolog GN2 microplates, according to the manufacturers' instructions except that the strips were inoculated with bacterial suspensions in artificial seawater medium (Choo et al., 2007) and incubated at $20{ }^{\circ} \mathrm{C}$ for 7 days. Ten different kinds of antimicrobial agents (listed in the species description) were tested by the diffusion plate method (Jorgensen et al., 1999) on MA incubated for 7 days at $20{ }^{\circ} \mathrm{C}$. The DNA G + C content was determined by using HPLC (Mesbah et al., 1989). Cellular fatty acid methyl esters were prepared from cultures grown on MA at $20{ }^{\circ} \mathrm{C}$ for 7 days, and also analysed according to the MIDI Microbial Identification System.

Phenotypic characteristics of strain IMCC $2115^{\mathrm{T}}$ were compared with other related species in the class Gammaproteobacteria (Table 1) and are summarized in the species description. In short, cells of strain IMCC $2115^{\mathrm{T}}$ were Gramstain-negative, obligately aerobic, chemoheterotrophic, nonflagellated, non-pigment producing and non-motile cocci $(0.38-0.96 \mu \mathrm{m}$ in diameter, see Supplementary Fig. S1 in IJSEM Online) that form beige to off-white and tiny colonies $\left(0.05 \mathrm{~mm}\right.$ in diameter). To check whether IMCC $2115^{\mathrm{T}}$ had light-harvesting systems, such as those carried by the cultured isolates of the OM60 (Cho et al., 2007) or SAR92 (Stingl et al., 2007) clades, PCR primers were used to detect pufL/pufM (found in the OM60 clade) and proteorhodopsin (found in the SAR92 clade). Primers pufLf and pufMr were used to amplify the pufLM genes for anoxygenic aerobic photoheterotrophy (Béjà et al., 2002; Kim et al., 2007; Nagashima et al., 1997). The following primer sets for proteorhodopsin detection were employed in this study: PRS1f/PRS1r (Sabehi et al., 2005); PRSAR11f/PRSAR11r (Giovannoni et al., 2005); PRfwdf/PRrev (Béjà et al., 2000; Sabehi et al., 2003); and RhodPal-f/RhodPal-r (de la Torre et al., 2003). Conclusively, no genes for photosynthetic reaction centres and proteorhodopsin could be determined for IMCC $2115^{\mathrm{T}}$ using PCR (data not shown). The major fatty acids found in strain IMCC $2115^{\mathrm{T}}$ were anteiso- $\mathrm{C}_{15: 0}$ $(67.6 \%)$, anteiso- $\mathrm{C}_{17: 0}(14.4 \%)$ and $\mathrm{C}_{16: 0}(6.9 \%)$, clearly different from the major fatty acids in other related species (Table 1 and supplementary Table S1).

As shown by the low 16S rRNA gene sequence similarity $(<92.2 \%)$ with related species, the distinct phylogenetic relationship (Fig. 1) and several differential phenotypic characteristics (Table 1), strain IMCC $2115^{\mathrm{T}}$ could not be assigned to any known genus. In conclusion, polyphasic evidence collected in this study demonstrates that strain IMCC $2115^{\mathrm{T}}$ belongs to a new species in a new genus of the class Gammaproteobacteria, for which the name Porticoccus litoralis gen. nov., sp. nov. is proposed.

\section{Description of Porticoccus gen. nov.}

Porticoccus (Por.ti.coc'cus. L. n. portus a harbour, haven, port; N.L. masc. n. coccus a coccus; N.L. masc. n. Porticoccus a coccus isolated from a harbour).

Gram-stain-negative, chemoheterotrophic, obligately aerobic, oxidase-positive and catalase-negative. Cells are cocci that are devoid of flagella. Requiring $\mathrm{NaCl}$ for growth. Visible pigment is not produced. Predominant cellular fatty acids are anteiso- $\mathrm{C}_{15: 0}$, anteiso- $\mathrm{C}_{17: 0}$ and $\mathrm{C}_{16: 0}$. The DNA G+C content of the type strain of the type species is $47.8 \mathrm{~mol} \%$. Light-harvesting genes including pufLM and proteorhodopsin are not present. Phylogenetically, the genus is affiliated to the class Gammaproteobacteria. The type species is Porticoccus litoralis.

\section{Description of Porticoccus litoralis sp. nov.}

Porticoccus litoralis (li.to.ra'lis. L. masc. adj. litoralis of or belonging to the sea shore).

Description is the same as that for the genus with the following additional properties. Cells are cocci, 0.38$0.96 \mu \mathrm{m}$ (typically $0.6 \mu \mathrm{m}$ ) in diameter and are devoid of flagellum and gliding motility. Colonies on MA (grown at $20{ }^{\circ} \mathrm{C}$ for 7 days) are circular, convex, entire and opaque. Colonies are beige to off-white and $0.05 \mathrm{~mm}$ in diameter. Temperature range for growth is $15-42{ }^{\circ} \mathrm{C}$, optimum 20 $25{ }^{\circ} \mathrm{C}$. Growth occurs at $\mathrm{pH}$ 5-11 (optimally at $\mathrm{pH} 7-8$ ) and $1.5-5.0 \% \mathrm{NaCl}$ on $\mathrm{MA}$ (optimally $3.5 \% \mathrm{NaCl}$ ). In API 20NE strips, arginine dihydrolase, urease and PNPG ( $\beta$-galactosidase) are negative. Indole production, hydrolysis of aesculin and gelatin, glucose fermentation and nitrate reduction are absent. In the API ZYM test, esterase (C4), esterase lipase (C8), leucine arylamidase, valine arylamidase and acid phosphatase are positive. Alkaline phosphatase, lipase (C14), cystine arylamidase, trypsin, $\alpha$-chymotrypsin, naphthol-AS-BI-phosphohydrolase, $\alpha$-galactosidase, $\beta$-galactosidase, $\beta$-glucuronidase, $\alpha$-glucosidase, $\beta$-glucosidase, $N$ acetyl- $\beta$-glucosaminidase, $\alpha$-mannosidase and $\alpha$-fucosidase are negative. For carbon source utilization (Biolog GN2 microplate), methylamine, glycerol, D-ribose, D-fructose, D-mannose, D-maltose, D-xylitol and L-lysine are positive; methanol, ethanol, D,L-glyceraldehyde, D-arabinose, D-galactose, $N$-acetyl-D-glucosamine, D-glucosamine, $\alpha$-Dglucose, rhamnose, cellobiose, lactose, melibiose, D-sucrose, D-trehalose, D-melezitose, D-raffinose, adonitol, arabitol, Dmannitol, myo-inositol, D-sorbitol, citric acid, gluconic acid, glucuronic acid, pyruvic acid, L-alanine, L-arginine, glycine, L-histidine, L-ornithine, L-proline and L-serine are weakly positive. Carbon source tests for itaconic acid, malonic acid, propionic acid, succinic acid, L-glutamic acid and L-leucine are negative. Susceptible to erythromycin $(15 \mu \mathrm{g})$ and rifampicin $(50 \mu \mathrm{g})$. Resistant to ampicillin $(10 \mu \mathrm{g})$, chloramphenicol $(25 \mu \mathrm{g})$, gentamicin $(10 \mu \mathrm{g})$, kanamycin $(30 \mu \mathrm{g})$, penicillin $\mathrm{G}(10 \mu \mathrm{g})$, streptomycin $(10 \mu \mathrm{g})$, tetracycline $(30 \mu \mathrm{g})$ and vancomycin $(30 \mu \mathrm{g})$. In cultures 
Table 1. Characteristics that differentiate strain IMCC $2115^{\top}$ from other genera

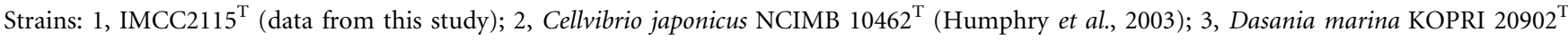
(Lee et al., 2007); 4, Haliea salexigens 3X/A02/235 ${ }^{\mathrm{T}}$ (Urios et al., 2008); 5, Marinimicrobium koreense KCTC 12356 ${ }^{\mathrm{T}}$ (Lim et al., 2006); 6, Microbulbifer agarilyticus JAMB A3 ${ }^{\mathrm{T}}$ (Miyazaki et al., 2008); 7, Microbulbifer hydrolyticus IRE-31 ${ }^{\mathrm{T}}$ (Gonzalez et al., 1997); 8, Saccharophagus degradans $2-40^{\mathrm{T}}$ (Gonzalez \& Weiner, 2000); 9, Simiduia agarivorans $\mathrm{SAl}^{\mathrm{T}}$ (Shieh et al., 2008); 10, Spongiibacter marinus $\mathrm{HAL} \mathrm{b}^{\mathrm{T}}$ (Graeber et al., 2008). +, Positive; -, negative; (+), weakly positive; ND, no data available. Data for strains $2-10$ were compiled from previous studies.

\begin{tabular}{|c|c|c|c|c|c|c|c|c|c|c|}
\hline Characteristic & 1 & 2 & 3 & 4 & 5 & 6 & 7 & 8 & 9 & 10 \\
\hline Cell shape & Cocci & Rods & $\begin{array}{l}\text { Irregular } \\
\text { rods }\end{array}$ & Rods & Short rods & Rods & $\begin{array}{l}\text { Straight } \\
\text { rods }\end{array}$ & Pleiotrophic & $\begin{array}{l}\text { Straight to } \\
\text { curved rods }\end{array}$ & Rods \\
\hline Flagellation & - & $\begin{array}{l}\text { Motile by } \\
\text { two polar } \\
\text { flagella }\end{array}$ & $\begin{array}{c}\text { Motile by } \\
\text { polar } \\
\text { flagella }\end{array}$ & $\begin{array}{l}\text { Single polar } \\
\text { flagellum }\end{array}$ & $\begin{array}{l}\text { Single } \\
\text { flagellum }\end{array}$ & $\mathrm{ND}$ & - & - & $\begin{array}{c}\text { Motile with } \\
\text { monotrichous } \\
\text { flagella } \\
(<1 \%)\end{array}$ & $\begin{array}{l}\text { Motile by } \\
\text { polar } \\
\text { flagellum }\end{array}$ \\
\hline $\begin{array}{l}\text { Optimal pH for } \\
\text { growth }\end{array}$ & $7-8$ & $\mathrm{ND}$ & $7.0-8.0$ & 8 & $7.0-7.5$ & $7.5-8.0$ & 7.5 & 7.5 & - & $7-9$ \\
\hline $\begin{array}{l}\mathrm{pH} \text { range for } \\
\text { growth }\end{array}$ & $5-11$ & $6-9$ & $7.0-10.0$ & $5.0-9.0$ & $6.0-10.5$ & $6.5-9.5$ & $6.5-8.5$ & $4.5-10.0$ & $7-10$ & $6.5-9.5$ \\
\hline $\begin{array}{l}\text { Salinity range for } \\
\text { growth }(\% \mathrm{w} / \mathrm{v})\end{array}$ & $1.5-5.0$ & 2 & $1-9$ & $0.7-7$ & $0-15$ & 7 & $0.58-5.8$ & 10 & $0.5-7$ & $1-7$ \\
\hline $\begin{array}{l}\text { Optimal salinity } \\
\text { range }(\% \mathrm{w} / \mathrm{v})\end{array}$ & 3.5 & ND & $3-4$ & 4.2 & $1-3$ & $2-3$ & $0.58-2.9$ & $2.3-3.5$ & $2-3$ & 3 \\
\hline $\begin{array}{l}\text { Optimal growth } \\
\text { temperature }\left({ }^{\circ} \mathrm{C}\right)\end{array}$ & $20-25$ & $\mathrm{ND}$ & $17-22$ & $25-30$ & $35-40$ & $31-35$ & 37 & $\mathrm{ND}$ & $30-35$ & $20-30$ \\
\hline $\begin{array}{l}\text { Temperature } \\
\text { range for growth } \\
\left({ }^{\circ} \mathrm{C}\right)\end{array}$ & $15-42$ & $17-47$ & $4-30$ & $10-37$ & $10-45$ & $10-38$ & $10-41$ & $4-37$ & $15-40$ & $10-40$ \\
\hline $\begin{array}{l}\text { Nitrate reduction } \\
\text { to nitrite }\end{array}$ & - & + & + & $\mathrm{ND}$ & - & + & - & - & + & $\mathrm{ND}$ \\
\hline Oxidase & + & + & + & + & - & + & + & + & + & + \\
\hline Catalase & - & + & + & + & - & + & + & + & + & $(+)$ \\
\hline \multicolumn{11}{|l|}{ Hydrolysis of: } \\
\hline Aesculin & - & + & - & ND & + & - & ND & ND & + & ND \\
\hline Agar & - & - & $\mathrm{ND}$ & $\mathrm{ND}$ & - & + & - & + & + & $\mathrm{ND}$ \\
\hline Gelatin & - & - & - & ND & - & + & + & + & + & $\mathrm{ND}$ \\
\hline $\begin{array}{l}\text { DNA G }+\mathrm{C} \\
\text { content }(\mathrm{mol} \%)\end{array}$ & 47.8 & 48.8 & 37 & 61 & 57 & 55.2 & 57.6 & 46 & 55.6 & 69.1 \\
\hline $\begin{array}{l}\text { Major fatty acids } \\
\text { (\% of total) }\end{array}$ & $\begin{array}{c}\text { ai- } \mathrm{C}_{15: 0} \\
(67.6), \\
\text { ai- } \mathrm{C}_{17: 0} \\
(14.4)\end{array}$ & $\begin{array}{l}\mathrm{C}_{16: 1} \\
(42.5) \\
\mathrm{C}_{18: 1} \\
(24.6)\end{array}$ & $\begin{array}{c}\mathrm{C}_{16: 1} \omega 7 c+ \\
\mathrm{i}-\mathrm{C}_{16: 0} \\
2-\mathrm{OH} \\
(45.3) \\
\mathrm{C}_{16: 0} \\
(18.4)\end{array}$ & $\begin{array}{c}\mathrm{C}_{17: 1} \omega 8 c \\
(23.9), \\
\mathrm{C}_{16: 1} \omega 7 c+ \\
\mathrm{i}-\mathrm{C}_{15: 0} \\
2-\mathrm{OH}(21.2)\end{array}$ & $\begin{array}{c}\mathrm{C}_{16: 0}(24.5), \\
\mathrm{C}_{19: 1} \\
\text { cyclo } \omega 8 c \\
(22.4) \\
\end{array}$ & $\begin{array}{r}\mathrm{C}_{18: 1} \\
(27.0), \\
\mathrm{i}-\mathrm{C}_{15: 0} \\
(21.0)\end{array}$ & $\begin{array}{c}\mathrm{i}-\mathrm{C}_{15: 0} \\
(26.2), \\
\mathrm{i}-\mathrm{C}_{17: 1} \\
\omega 9 c(25.4)\end{array}$ & $\begin{array}{l}\mathrm{C}_{16: 0} \\
(37.0) \\
\mathrm{C}_{14: 0} \\
(15.0)\end{array}$ & $\begin{array}{c}\mathrm{C}_{16: 1} \omega 7 c+ \\
\mathrm{i}-\mathrm{C}_{15: 0} 2-\mathrm{OH} \\
(28.6), \\
\mathrm{C}_{17: 1} \omega 8 c \\
(22.8)\end{array}$ & $\begin{array}{l}\mathrm{C}_{17: 1} \omega 8 c \\
(51.7), \\
\mathrm{C}_{17: 0}(9.6)\end{array}$ \\
\hline
\end{tabular}

grown on $\mathrm{MA}$ at $20{ }^{\circ} \mathrm{C}$ for 7 days, the major cellular fatty acids are anteiso- $\mathrm{C}_{15: 0}$, anteiso- $\mathrm{C}_{17: 0}, \mathrm{C}_{16: 0}$, iso- $\mathrm{C}_{17: 0}$, iso- $\mathrm{C}_{15: 0}$ and anteiso- $\mathrm{C}_{19: 0}$ (Table 1 and Supplementary Table S1).

The type strain, IMCC $2115^{\mathrm{T}}\left(=\mathrm{KCCM} 42369^{\mathrm{T}}=\mathrm{NBRC}\right.$ $102686^{\mathrm{T}}$ ), was isolated from coastal seawater of the Yellow Sea in Korea $\left(37^{\circ} 19^{\prime} \mathrm{N} 126^{\circ} 33^{\prime} \mathrm{E}\right)$.

\section{Acknowledgements}

This study was supported by the Korea Research Foundation Grant funded by the Korean Government (MEST) (KRF-2007-314-C00265) and by the 21C Frontier Program of Microbial Genomics and Applications from the MEST, Korea.

\section{References}

Béjà, O., Aravind, L., Koonin, E. V., Suzuki, M. T., Hadd, A., Nguyen, L. P., Jovanovich, S. B., Gates, C. M., Feldman, R. A. \& other authors (2000). Bacterial rhodopsin: evidence for a new type of phototrophy in the sea. Science 289, 1902-1906.

Béjà, O., Suzuki, M. T., Heidelberg, J. F., Nelson, W. C., Preston, C. M., Hamada, T., Eisen, J. A., Fraser, C. M. \& DeLong, E. F. (2002). Unsuspected diversity among marine aerobic anoxygenic phototrophs. Nature 415, 630-633. 
Cho, J.-C. \& Giovannoni, S. J. (2003). Parvularcula bermudensis gen. nov., sp. nov., a marine bacterium that forms a deep branch in the $\alpha$-Proteobacteria. Int J Syst Evol Microbiol 53, 1031-1036.

Cho, J. C. \& Giovannoni, S. J. (2004). Cultivation and growth characteristics of a diverse group of oligotrophic marine Gammaproteobacteria. Appl Environ Microbiol 70, 432-440.

Cho, J. C. \& Giovannoni, S. J. (2006). Pelagibaca bermudensis gen. nov., sp. nov., a novel marine bacterium within the Roseobacter clade in the order Rhodobacterales. Int J Syst Evol Microbiol 56, 855-859.

Cho, J. C., Stapels, M. D., Morris, R. M., Vergin, K. L., Schwalbach, M. S., Givan, S. A., Barofsky, D. F. \& Giovannoni, S. J. (2007). Polyphyletic photosynthetic reaction centre genes in oligotrophic marine Gammaproteobacteria. Environ Microbiol 9, 1456-1463.

Choi, D. H., Cho, J.-C., Lanoil, B. D., Giovannoni, S. J. \& Cho, B. C. (2007). Maribius salinus gen. nov., sp. nov., isolated from a solar saltern and Maribius pelagius sp. nov., cultured from the Sargasso Sea, belonging to the Roseobacter clade. Int J Syst Evol Microbiol 57, 270275.

Choo, Y. J., Lee, K., Song, J. \& Cho, J. C. (2007). Puniceicoccus vermicola gen. nov., sp. nov., a novel marine bacterium, and description of Puniceicoccaceae fam. nov., Puniceicoccales ord. nov., Opitutaceae fam. nov., Opitutales ord. nov. and Opitutae classis nov. in the phylum 'Verrucomicrobia'. Int J Syst Evol Microbiol 57, 532-537.

Chun, J., Lee, J. H., Jung, Y., Kim, M., Kim, S., Kim, B. K. \& Lim, Y. W. (2007). EzTaxon: a web-based tool for the identification of prokaryotes based on $16 \mathrm{~S}$ ribosomal RNA gene sequences. Int J Syst Evol Microbiol 57, 2259-2261.

de la Torre, J. R., Christianson, L. M., Béjà, O., Suzuki, M. T., Karl, D. M., Heidelberg, J. \& DeLong, E. F. (2003). Proteorhodopsin genes are distributed among divergent marine bacterial taxa. Proc Natl Acad Sci U S A 100, 12830-12835.

Distel, D. L., Morrill, W., MacLaren-Toussaint, N., Franks, D. \& Waterbury, J. (2002). Teredinibacter turnerae gen. nov., sp. nov., a dinitrogen-fixing, cellulolytic, endosymbiotic $\gamma$-proteobacterium isolated from the gills of wood-boring molluscs (Bivalvia: Teredinidae). Int J Syst Evol Microbiol 52, 2261-2269.

Eilers, H., Pernthaler, J., Peplies, J., Glöckner, F. O., Gerdts, G. \& Amann, R. (2001). Isolation of novel pelagic bacteria from the German Bight and their seasonal contributions to surface picoplankton. Appl Environ Microbiol 67, 5134-5142.

Felsenstein, J. (1981). Evolutionary trees from DNA sequences: a maximum likelihood approach. J Mol Evol 17, 368-376.

Felsenstein, J. (1985). Confidence limits on phylogenies: an approach using the bootstrap. Evolution 39, 783-791.

Fitch, W. M. (1971). Toward defining the course of evolution: minimum change for a specific tree topology. Syst Zool 27, 401-410.

Giovannoni, S. J., Bibbs, L., Cho, J. C., Stapels, M. D., Desiderio, R., Vergin, K. L., Rappé, M. S., Laney, S., Wilhelm, L. J. \& other authors (2005). Proteorhodopsin in the ubiquitous marine bacterium SAR11. Nature 438, 82-85.

Glatz, R. E., Lepp, P. W., Ward, B. B. \& Francis, C. A. (2006) Planktonic microbial community composition across steep physical/ chemical gradients in permanently ice-covered Lake Bonney, Antarctica. Geobiology 4, 53-67.

González, J. M. \& Weiner, R. M. (2000). Phylogenetic characterization of marine bacterium strain 2-40, a degrader of complex polysaccharides. Int J Syst Evol Microbiol 50, 831-834.

González, J. M., Mayer, F., Moran, M. A., Hodson, R. E. \& Whitman, W. B. (1997). Microbulbifer hydrolyticus gen. nov., sp. nov., and Marinobacterium georgiense gen. nov., sp. nov., two marine bacteria from a lignin-rich pulp mill waste enrichment community. Int J Syst Evol Microbiol 47, 369-376.
Graeber, I., Kaesler, I., Borchert, M. S., Dieckmann, R., Pape, T., Lurz, R., Nielsen, P., von Döhren, H., Michaelis, W. \& Szewzyk, U. (2008). Spongiibacter marinus gen. nov., sp. nov., a halophilic marine bacterium isolated from the boreal sponge Haliclona sp. 1. Int J Syst Evol Microbiol 58, 585-590.

Humphry, D. R., Black, G. W. \& Cummings, S. P. (2003). Reclassification of 'Pseudomonas fluorescens subsp. cellulosa' NCIMB 10462 (Ueda et al. 1952) as Cellvibrio japonicus sp. nov. and revival of Cellvibrio vulgaris sp. nov., nom. rev. and Cellvibrio fulvus sp. nov., nom. rev. Int J Syst Evol Microbiol 53, 393-400.

Jorgensen, J. H., Turnidge, J. D. \& Washington, J. A. (1999). Antibacterial susceptibility tests: dilution and disk diffusion methods. In Manual of Clinical Microbiology, pp. 1526-1543. Edited by P. R. Murray, E. J. Baron, M. A. Pfaller, F. C. Tenover \& R. H. Yolken. Washington, DC: American Society for Microbiology.

Kim, M. K., Schubert, K., Im, W.-T., Kim, K.-H., Lee, S.-T. \& Overmann, J. (2007). Sphingomonas kaistensis sp. nov., a novel alphaproteobacterium containing pufLM genes. Int $J$ Syst Evol Microbiol 57, 1527-1534.

Lee, Y. K., Hong, S. G., Cho, H. H., Cho, K. H. \& Lee, H. K. (2007). Dasania marina gen. nov., sp. nov., of the order Pseudomonadales, isolated from Arctic marine sediment. J Microbiol 45, 505-509.

Lim, G. E. \& Haygood, M. G. (2004). 'Candidatus Endobugula glebosa,' a specific bacterial symbiont of the marine bryozoan Bugula simplex. Appl Environ Microbiol 70, 4921-4929.

Lim, J.-M., Jeon, C. O., Lee, J.-C., Song, S.-M., Kim, K.-Y. \& Kim, C.-J. (2006). Marinimicrobium koreense gen. nov., sp. nov. and Marinimicrobium agarilyticum sp. nov., novel moderately halotolerant bacteria isolated from tidal flat sediment in Korea. Int J Syst Evol Microbiol 56, 653-657.

Ludwig, W., Strunk, O., Westram, R., Richter, L., Meier, H., Yadhukumar, Buchner, A., Lai, T., Steppi, S. \& other authors (2004). ARB: a software environment for sequence data. Nucleic Acids Res 32, 1363-1371.

Mesbah, M., Premachandran, U. \& Whitman, W. B. (1989). Precise measurement of the $\mathrm{G}+\mathrm{C}$ content of deoxyribonucleic acid by highperformance liquid chromatography. Int J Syst Bacteriol 39, 159-167.

Miyazaki, M., Nogi, Y., Ohta, Y., Hatada, Y., Fujiwara, Y., Ito, S. \& Horikoshi, K. (2008). Microbulbifer agarilyticus sp. nov. and Microbulbifer thermotolerans sp. nov., agar-degrading bacteria isolated from deep-sea sediment. Int J Syst Evol Microbiol 58, 1128-1133.

Nagashima, K. V. P., Hiraishi, A., Shimada, K. \& Matsuura, K. (1997). Horizontal transfer of genes coding for the photosynthetic reaction centers of purple bacteria. J Mol Evol 45, 131-136.

Sabehi, G., Massana, R., Bielawski, J. P., Rosenberg, M., Delong, E. F. \& Béjà, O. (2003). Novel proteorhodopsin variants from the Mediterranean and Red Seas. Environ Microbiol 5, 842-849.

Sabehi, G., Loy, A., Jung, K. H., Partha, R., Spudich, J. L., Isaacson, T., Hirschberg, J., Wagner, M. \& Béjà, O. (2005). New insights into metabolic properties of marine bacteria encoding proteorhodopsins. PLoS Biol 3, e273.

Saitou, N. \& Nei, M. (1987). The neighbor-joining method: a new method for reconstructing phylogenetic trees. Mol Biol Evol 4, 406425 .

Shieh, W. Y., Liu, T. Y., Lin, S. Y., Jean, W. D. \& Chen, J.-S. (2008). Simiduia agarivorans gen. nov., sp. nov., a marine, agarolytic bacterium isolated from shallow coastal water from Keelung, Taiwan. Int J Syst Evol Microbiol 58, 895-900.

Smibert, R. M. \& Krieg, N. R. (1994). Phenotypic characterization. In Methods for General and Molecular Microbiology, pp. 611-654. Edited by P. Gerhardt, R. G. E. Murray, W. A. Wood \& N. R. Krieg. Washington, DC: American Society for Microbiology. 
Stingl, U., Desiderio, R. A., Cho, J. C., Vergin, K. L. \& Giovannoni, S. J. (2007). The SAR92 clade: an abundant coastal clade of culturable marine bacteria possessing proteorhodopsin. Appl Environ Microbiol 73, 2290-2296.

Swofford, D. L. (2002). PAUP*: Phylogenetic analysis using parsimony (and other methods), version 4. Sunderland, MA: Sinauer Associates.

Tanaka, T., Yan, L. \& Burgess, J. G. (2003). Microbulbifer arenaceous sp. nov., a new endolithic bacterium isolated from the inside of red sandstone. Curr Microbiol 47, 412-416.

Urios, L., Intertaglia, L., Lesongeur, F. \& Lebaron, P. (2008). Haliea salexigens gen. nov., sp. nov., a member of the Gammaproteobacteria from the Mediterranean Sea. Int J Syst Evol Microbiol 58, 1233-1237.

Yoon, J.-H., Kim, H., Kang, K. H., Oh, T.-K. \& Park, Y.-H. (2003a). Transfer of Pseudomonas elongata Humm 1946 to the genus
Microbulbifer as Microbulbifer elongatus comb. nov. Int J Syst Evol Microbiol 53, 1357-1361.

Yoon, J.-H., Kim, I.-G., Shin, D.-Y., Kang, K. H. \& Park, Y.-H. (2003b). Microbulbifer salipaludis sp. nov., a moderate halophile isolated from a Korean salt marsh. Int J Syst Evol Microbiol 53, 53-57.

Yoon, J.-H., Kim, I.-G., Oh, T.-K. \& Park, Y.-H. (2004). Microbulbifer maritimus sp. nov., isolated from an intertidal sediment from the Yellow Sea, Korea. Int J Syst Evol Microbiol 54, 1111-1116.

Yoon, J.-H., Jung, S.-Y., Kang, S.-J. \& Oh, T.-K. (2007). Microbulbifer celer sp. nov., isolated from a marine solar saltern of the Yellow Sea in Korea. Int J Syst Evol Microbiol 57, 2365-2369.

Zeng, R., Zhao, J., Zhang, R. \& Lin, N. (2005). Bacterial community in sediment from the Western Pacific 'Warm Pool' and its relationship to environment. Sci China Ser D Earth Sci 48, 282-290. 